as seen in profile, whatever else it may have been, was ceriainly not spherical. Then I saw that in one eye the pupil had been converted into a beautiful vertical slit, and I learnt that the operation had been followed by a great improvement in the vision. I further saw the same change effected in the other eye. I was simple enough to consider that I had witnessed a triumph of scientitic ophthalmic surgery in a well-devised and well-executed operation; but that was quite from a tyro's point of view.

Still, having some slight knowledge of the properties of lenses, I asked myself how it came to pass that cutting off the lateral marginal rays only could so greatly diminish the confusion, as to effect the improvement of sight which seemed to have followed; and knowing nothing about horizontal and vertical meridians, I found an answer satisfactory to myself in $\mathrm{m} y$ own experience. I am a shortsighted individual, and I remembered how, before I took to spectacles, I obtained more distinct distant vision by nearly closing my eyes. Exactly, said I; just as I got better definition by shutting out marginal rays above and below, although $I$ could not get rid of them all round, the operation has done good to her by intercepting the equatorial marginal rays. And, besides, I thought, the patient has only to half-close her eyes and she will cut off those rays not interfered with by the new disposition of the iris, and so admit none but central rays.

I dare say Mr. Carter may be less satisfied with this explanation than I was myself, in which case he will no doubt set me right in a way which I shall remember; but in the meantime I shall continue to think there is something in it, and that the case was, after all, one of those usually termed conical cornea. I hope the question will be set at rest by the production of the patient.

I am, Sir, your obedient servant,

Seymour-street, Feb. 28th, 1369.

W. H. BroAdBENT.

\section{POOR-LAW MEDICAL SERVICE.}

To the Editor of THE LANCET.

SIR,-In The LANCET of the 20th inst., in an article headed "Poor-law Medical Service" (p. 267), you state, "This appears to have been instigated by a member of our profession, Mr. John Clay, whose conduct is inexplicable."

Now I beg respectfully, but most emphatically, to deny that the reduction of the medical officers in the Birmingham parish from eight to five was instigated by me; and, pending other proceedings, I may add that at the proper time I shall be able to show that my conduct in this matter is not so "inexplicable" as you have led your readers to suppose. I am, Sir, yours faithfully, JOHN CLAY.

February 24 th, 1869 .

\section{THE INJECTION OF PERCHLORIDE OF' IRON} IN POST-PARTUM HAMORRHAGE.

To the Editor of THE LaNCET.

SiR,-Having been recently from home, I did not read until within a day or two, Dr. Barnes's letter on the above subject in your number dated the 30th of January. I would most strenuously call the attention of every country practitioner to his lucid remarks, for having myself used the same remedy (wholly independently of Dr. Barnes) in many instances since October, 1859, when I first plugged the vagina with the perchloride in an alarming case of abortion, I am in a position most fully to endorse every word he has said on the subject.

The remedy is invaluable to us provincials, who are so often obliged to work single-handed, miles and hours from any skilled assistance. Should you deem my experience of the perchloride worthy of insertion in THE LANCET, I shall be happy to afford it, as I am anxious that every obstetric practitioner should be made aware of its value.

In April, 1865, I read a paper on the subject at a meeting of the West Somerset Branch of the British Medical Association, in Taunton. The memhers present requested that I would send it for publication in their Journal, which I did in October last, giving also my further experience.

The editor, for reasons best known to himself, has not acceded to this request; and I do not consider myself guilty of any want of courtesy towards him, when I humbly offer ny crude remarks to you.

I am, Sir, your obedient servant,

South Petherton, Somerset,

HUGH NORRIS. Feb. 16th, 1869 .

\section{To the Editor of THE IJANCET.}

Sir,-My eye has just caught, in your impression of the 30 th ult., a statement of some importance in a communication from Dr. Barnes:-

"I have a strong suspicion that in one case of early abortion, an injection made too forcibly by means of a caoutchouc bottle was the cause of a fatal catastrophe. The patient died almost suddenly soon after the injection, with symptoms resembling those consequent upon air entering the circulation."

This is the only casualty specified against the use of the perchloride of iron injection, and precautions of some elaborateness are devised to prevent a recurrence. It would be well, therefore, to know whether we have before us a real peril or an imaginary danger.

If Dr. Barnes expressed anything more than " a strong suspicion," I would, perhaps, hold my peace; but as a suspicion, however strong, is a poor foundation for precautions, and as these, which always alarm the timid, are advised about an operation simple and "in itself safe," it is right that the profession should, if possible, be relieved from a terror which, upon examination, may prove to be not more than the phantom of a suspicion. If Dr. Barnes will give the length of the interval between the injection and the dissolution, with a few of the symptoms, we may be able to form some estimate of the value of his suspicion; and it would be also interesting to know, if he were not himself the administerer, what ground he has for stating that an injection was "made too forcibly."

Doubting that such a catastrophe as death, "with symptoms resembling those consequent upon air entering the circulation," can arise from the employment of a "caoutchouc bottle" to inject the cavity of the uterus, I am desirous of having an operation "in itself safe" left in all its original simplicity, and an obstacle removed from the way of those who have to meet a serious emergency.

I am, Sir, your obedient servant,

Tindale-place, N., February 9 th, 1869.

W. J. BRADFORD.

\section{CLINICAL SURGERY AT EDINBURGH.}

\section{To the Editor of ThE LANCET.}

SIn,-I have read with much surprise the correspondence which has taken place in your columns between Professors Syme and Bennett; and in your last impression some remarks are made by Professor Bennett which are calculated to convey a false notion as to the mode of teaching clinical surgery in this school. An attack is made on Mr. Syme's mode of teaching; and, according to Professor Bennett's view, our chair of clinical surgery is greatly neglected so far as teaching goes.

Now, as an alummus of this school, $I$ beg to state that the general opinion of the students is that Mir. Syme's mocie of teaching is in every respect satisfactory, as the large attendance at his class testifies.

As to Mr. Syme's pupils complaining of his teaching to others, as Professor Bennett alleges, I may say that such a proceeding was, on the part of these gentlemen, most unwarranted and ungentlemaniy; and $\mathrm{I}$ am sure that $\mathrm{Mr}$. Syme is at all times willing to hear objections or complaints, and to do his best to remedy such, if possible.

In conclusion, so long as Mr. Syme is connected with us, he will be regarded with the highest esteem, and the Edinburgh school, seconded by his efforts, will, $I$ am sure, send forth her almmi in ihe liberal spirit which is professed by nearly ail her teachers.

Trusting you will give these remarks a place in your next impression, and enclosing my card, I am, Sir, your obedient servant,

Edinburgh, Ecb. 18th, 1869. 